\title{
Roseovarius aestuarii sp. nov., isolated from a tidal flat of the Yellow Sea in Korea
}

\author{
Jung-Hoon Yoon, So-Jung Kang and Tae-Kwang Oh
}

Correspondence

Jung-Hoon Yoon

jhyoon@kribb.re.kr
Korea Research Institute of Bioscience and Biotechnology (KRIBB), PO Box 115, Yusong, Taejon, Republic of Korea

\begin{abstract}
A Gram-negative, motile, ovoid to rod-shaped bacterial strain, designated strain SMK-122 ${ }^{\top}$, was isolated from a Yellow Sea tidal flat located on the coast of Korea. Strain SMK-122 ${ }^{\top}$ grew optimally at $\mathrm{pH} 7.0-8.0$ and $30{ }^{\circ} \mathrm{C}$. It contained $\mathrm{Q}-10$ as the predominant ubiquinone and possessed $\mathrm{C}_{18: 1} \omega 7 c$ and $\mathrm{C}_{16: 0}$ as the major fatty acids. The DNA $\mathrm{G}+\mathrm{C}$ content was $58.6 \mathrm{~mol} \%$. A phylogenetic analysis based on 16S rRNA gene sequences showed that strain SMK $-122^{\top}$ fell within the genus Roseovarius, being closest to Roseovarius nubinhibens ISM $^{\top}$; the sequence similarities with respect to Roseovarius species ranged from 94.9 to $97.3 \%$. The mean value for DNA-DNA relatedness between strain SMK $-122^{\top}$ and Rva. nubinhibens DSM $15170^{\top}$ was $13 \%$. Differential phenotypic properties of SMK $-122^{\top}$, together with its phylogenetic and genetic distinctiveness, revealed that this strain is distinct from recognized Roseovarius species. On this basis, strain SMK $-122^{\top}$ represents a novel species of the genus Roseovarius, for which the name Roseovarius aestuarii sp. nov. is proposed. The type strain is SMK-122 ${ }^{\top}$ $\left(=\right.$ KCTC $22174^{\top}=$ CCUG $\left.55325^{\top}\right)$.
\end{abstract}

The genus Roseovarius, a member of the Alphaproteobacteria, was proposed by Labrenz et al. (1999) and currently includes Roseovarius tolerans (Labrenz et al., 1999), Roseovarius nubinhibens (González et al., 2003), Roseovarius crassostreae (Boettcher et al., 2005) and Roseovarius mucosus (Biebl et al., 2005). In this study, we report the taxonomic characterization of a Roseovarius-like bacterial strain, SMK- $122^{\mathrm{T}}$, isolated from a tidal flat sediment of the Yellow Sea, Korea.

Strain SMK-122 $2^{\mathrm{T}}$ was isolated from a Yellow Sea tidal flat, collected near Saemankum, Korea. A standard dilution technique was used for the isolation: the sample was suspended and diluted in a $0.85 \%(\mathrm{w} / \mathrm{v}) \mathrm{NaCl}$ solution, plated on marine agar 2216 (MA; Difco) and incubated at $25{ }^{\circ} \mathrm{C}$. The type strains of the four Roseovarius species, Rva. tolerans DSM $11457^{\mathrm{T}}$, Rva. nubinhibens DSM $15170^{\mathrm{T}}$, Rva. crassostreae DSM $16950^{\mathrm{T}}$ and Rva. mucosus DSM $17069^{\mathrm{T}}$, which were used as reference strains for phenotypic characterization and DNA-DNA hybridization, were obtained from the Deutsche Sammlung von Mikroorganismen und Zellkulturen, Braunschweig, Germany. The morphological, physiological and biochemical characteristics of strain SMK$122^{\mathrm{T}}$ were investigated using routine cultivation on MA at $30{ }^{\circ} \mathrm{C}$. The cell morphology was examined by using light microscopy (E600; Nikon) and transmission electron microscopy. Flagellation was determined using a Philips CM-20 transmission electron microscope with cells from exponentially growing cultures: for this purpose, the cells

The GenBank/EMBL/DDBJ accession number for the 16S rRNA gene sequence of strain SMK-122 ${ }^{\top}$ is EU156066. were negatively stained with $1 \%(\mathrm{w} / \mathrm{v})$ phosphotungstic acid and the grids were examined after being air-dried. Growth under anaerobic conditions was determined after incubation in a Forma anaerobic chamber on MA and MA supplemented with potassium nitrate $(0.1 \%, \mathrm{w} / \mathrm{v})$, both of which had been prepared anaerobically using nitrogen. Growth in the absence of $\mathrm{NaCl}$ was investigated using trypticase soy broth prepared according to the formula of the Difco medium except that $\mathrm{NaCl}$ was excluded. Growth at various $\mathrm{NaCl}$ concentrations $(0.5 \%$ and $1.0-10.0 \%$, w/v, in increments of $1.0 \%$ ) was investigated in marine broth 2216 (MB; Difco) or trypticase soy broth (Difco). Growth at various temperatures $\left(4,10,15,20,22,25,28\right.$ and $30-40{ }^{\circ} \mathrm{C}$, in increments of $1{ }^{\circ} \mathrm{C}$ ) was measured on MA. For in vivo pigment-absorption spectrum analysis, strain SMK-122 ${ }^{\mathrm{T}}$ was cultivated aerobically in the dark at $30{ }^{\circ} \mathrm{C}$ in MB. The culture was washed twice by centrifugation using a MOPS buffer (MOPS/NaOH, $0.01 \mathrm{M} ; \mathrm{KCl}, 0.1 \mathrm{M} ; \mathrm{MgCl}_{2}, 0.001 \mathrm{M}$; $\mathrm{pH}$ 7.5) and disrupted by sonication with a Branson Sonifier S-450. After removal of cell debris by centrifugation, the absorption spectrum of the supernatant was examined on a Beckman Coulter DU800 spectrophotometer. Catalase and oxidase activities and hydrolysis of casein, starch and Tweens 20, 40, 60 and 80 were determined as described by Cowan \& Steel (1965). Hydrolysis of hypoxanthine, tyrosine and xanthine was tested on MA using the substrate concentrations described by Cowan \& Steel (1965). Hydrolysis of aesculin, gelatin and urea and reduction of nitrate were investigated as described previously (Lányí, 1987 ) with the modification that artificial seawater was used 
for the preparation of media. The artificial seawater contained $\left(1^{-1}\right.$ distilled water) $23.6 \mathrm{~g} \mathrm{NaCl}, 0.64 \mathrm{~g} \mathrm{KCl}$, $4.53 \mathrm{~g} \mathrm{MgCl}_{2} \cdot 6 \mathrm{H}_{2} \mathrm{O}, 5.94 \mathrm{~g} \mathrm{MgSO}_{4} .7 \mathrm{H}_{2} \mathrm{O}$ and $1.3 \mathrm{~g}$ $\mathrm{CaCl}_{2} \cdot 2 \mathrm{H}_{2} \mathrm{O}$ (Bruns et al., 2001). $\mathrm{H}_{2} \mathrm{~S}$ production was tested as described previously (Bruns et al., 2001). Susceptibility to antibiotics was investigated on MA plates by using antibiotic discs with the following amounts: polymyxin B (100 U), streptomycin $(50 \mu \mathrm{g})$, penicillin $\mathrm{G}$ (20 U), chloramphenicol $(100 \mu \mathrm{g})$, ampicillin $(10 \mu \mathrm{g})$, cephalothin $(30 \mu \mathrm{g})$, gentamicin $(30 \mu \mathrm{g})$, novobiocin $(5 \mu \mathrm{g})$ and tetracycline $(30 \mu \mathrm{g})$. Acid production from carbohydrates was tested as described by Leifson (1963). The utilization of various substrates for growth was determined as described by Baumann \& Baumann (1981), using

Table 1. Differential phenotypic characteristics of strain SMK-122 $2^{\top}$ and type strains of Roseovarius species

Strains: 1 , SMK- $122^{\mathrm{T}}$; 2, Rva. tolerans DSM $11457^{\mathrm{T}}$; 3, Rva. nubinhibens DSM $15170^{\mathrm{T}}$; 4, Rva. crassostreae DSM 16950 ; 5 , Rva. mucosus DSM $17069^{\mathrm{T}}$. Data were obtained in this study unless indicated. All of the strains are positive for the following: catalase and oxidase activities, growth at $37{ }^{\circ} \mathrm{C}$ (data for reference type strains taken from the papers indicated in the footnote), utilization of acetate, esterase (C4) and esterase lipase (C8) and susceptibility to ampicillin, carbenicillin, cephalothin, chloramphenicol, gentamicin, kanamycin, neomycin, penicillin G and streptomycin. All of the strains are negative for the following: Gram stain (data for reference type strains taken from the papers indicated in the footnote), hydrolysis of aesculin, gelatin, starch, Tween 80 and urea, utilization of D-glucose, D-fructose, D-galactose, cellobiose, D-mannose, trehalose, D-xylose, Larabinose, sucrose, maltose, benzoate and salicin, acid production from L-arabinose, cellobiose, D-fructose, D-galactose, D-glucose, lactose, maltose, D-mannose, melezitose, melibiose, raffinose, L-rhamnose, sucrose, trehalose, D-xylose, myo-inositol and D-sorbitol, lipase (C14), valine arylamidase, cystine arylamidase, trypsin, $\alpha$-chymotrypsin, acid phosphatase, naphthol-AS-BI-phosphohydrolase, $\alpha$-galactosidase, $\beta$-galactosidase, $\beta$ glucuronidase, $\alpha$-glucosidase, $\beta$-glucosidase, $N$-acetyl- $\beta$-glucosaminidase, $\alpha$-mannosidase and $\alpha$-fucosidase and susceptibility to lincomycin, polymyxin B and tetracycline. + , Positive; - , negative; $\mathrm{w}$, weakly positive; ND, no data available.

\begin{tabular}{|c|c|c|c|c|c|}
\hline Characteristic & 1 & 2 & 3 & 4 & 5 \\
\hline Cell shape & Ovoid to rod-shaped & $\operatorname{Rods}^{a *}$ & $\operatorname{Rods}^{b}$ & Ovoid to rod-shaped ${ }^{c}$ & Rods $^{d}$ \\
\hline Motility & + & $+1-^{a}$ & $+^{b}$ & $--^{c}$ & $-^{d}$ \\
\hline Colony colour on MA & Cream & Cream & Cream & Cream & Pale yellow \\
\hline Bacteriochlorophyll $a$ production & - & $+^{a}$ & ND & $-^{c}$ & Trace $^{d}$ \\
\hline \multicolumn{6}{|l|}{ Growth at: } \\
\hline $4{ }^{\circ} \mathrm{C}$ & - & $+{ }^{a}$ & $-{ }^{b}$ & $--^{c}$ & $\mathrm{ND}$ \\
\hline $10{ }^{\circ} \mathrm{C}$ & + & $++^{a}$ & $+^{b}$ & $\mathrm{ND}$ & $\mathrm{ND}$ \\
\hline $40{ }^{\circ} \mathrm{C}$ & - & $+^{a}$ & $+^{b}$ & $\mathrm{ND}$ & $+^{d}$ \\
\hline Reduction of nitrate to nitrite & + & - & - & + & - \\
\hline \multicolumn{6}{|l|}{ Hydrolysis of: } \\
\hline Casein & + & - & - & - & - \\
\hline Hypoxanthine & + & - & - & + & - \\
\hline Xanthine & - & - & - & $\mathrm{w}$ & $\mathrm{w}$ \\
\hline Tyrosine & - & - & - & + & - \\
\hline Tween 20 & - & - & $\mathrm{w}$ & - & + \\
\hline Tween 40 & - & - & - & $\mathrm{w}$ & + \\
\hline Tween 60 & - & - & - & $\mathrm{w}$ & + \\
\hline \multicolumn{6}{|l|}{ Utilization of: } \\
\hline Citrate & - & - & - & + & - \\
\hline Formate & - & - & - & - & + \\
\hline L-Malate & + & + & - & + & + \\
\hline Pyruvate & + & + & - & + & + \\
\hline Succinate & + & - & - & + & + \\
\hline L-Glutamate & - & - & - & + & + \\
\hline \multicolumn{6}{|l|}{ Acid production from: } \\
\hline D-Ribose & - & - & - & - & + \\
\hline D-Mannitol & - & + & - & - & - \\
\hline \multicolumn{6}{|l|}{ Enzyme activities (API ZYM) } \\
\hline Alkaline phosphatase & $\mathrm{w}$ & + & + & + & - \\
\hline Leucine arylamidase & - & + & + & + & + \\
\hline \multicolumn{6}{|l|}{ Susceptibility to antibiotics } \\
\hline Novobiocin & - & - & - & + & - \\
\hline Oleandomycin & - & - & - & + & - \\
\hline
\end{tabular}

*Data obtained from: a, Labrenz et al. (1999); b, González et al. (2003); c, Boettcher et al. (2005); d, Biebl et al. (2005). 
supplementation with $2 \%(\mathrm{v} / \mathrm{v})$ Hutner's mineral salts solution (Cohen-Bazire et al., 1957) and $1 \%(\mathrm{v} / \mathrm{v})$ vitamin solution (Staley, 1968). Enzyme activities were determined by using the API ZYM system (bioMérieux).

Cell biomass for DNA extraction and for isoprenoid quinone analysis was obtained from cultures grown in $\mathrm{MB}$ at $30{ }^{\circ} \mathrm{C}$. Chromosomal DNA was isolated and purified according to the method described by Yoon et al. (1996), except that RNase T1 was used in combination with RNase A to minimize the contamination of RNA. The 16S rRNA gene was amplified by using a PCR with two universal primers, 5'-GAGTTTGATCCTGGCTCAG-3' and 5' -AGAAAGGAGGTGATCCAGCC-3', as described previously (Yoon et al., 1998). Sequencing of the amplified $16 \mathrm{~S}$ rRNA gene and phylogenetic analysis were performed as described by Yoon et al. (2003). Isoprenoid quinones were analysed as described by Komagata \& Suzuki (1987) using reversed-phase HPLC. For cellular fatty acid analysis, cell mass of strain SMK-122 $2^{\mathrm{T}}$ and the type strains of the four Roseovarius species was harvested from MA plates after cultivation for 3 days at $30^{\circ} \mathrm{C}$. The fatty acids were extracted and fatty acid methyl esters were prepared according to the standard protocol of the MIDI/Hewlett Packard Microbial Identification System (Sasser, 1990). The DNA G $+\mathrm{C}$ content was determined by using the method of Tamaoka \& Komagata (1984) with the modification that DNA was hydrolysed using nuclease P1 (Sigma) and the resultant nucleotides were analysed by reversed-phase HPLC. DNA-DNA hybridization was performed fluorometrically according to the method of Ezaki et al. (1989), using photobiotin-labelled DNA probes and microdilution wells. Hybridization was performed with five replications for each sample. The highest and lowest values obtained in each sample were excluded and the means of the remaining three values were quoted as DNA-DNA relatedness values.

Morphological, cultural, physiological and biochemical characteristics of strain SMK- $122^{\mathrm{T}}$ are given in the species description (see below) or are shown in Table 1. The almost-complete 16S rRNA gene sequence of strain SMK$122^{\mathrm{T}}$ determined in this study comprised $1421 \mathrm{nt}$, representing approximately $96 \%$ of the Escherichia coli $16 \mathrm{~S}$ rRNA gene sequence. In the phylogenetic tree obtained using the neighbour-joining algorithm, strain SMK-122 fell within the clade comprising Roseovarius species, clustering in particular with the type strain of $R v a$. nubinhibens at a bootstrap resampling value of $74.7 \%$ (Fig. 1). Strain SMK-122 $2^{\mathrm{T}}$ exhibited $97.3 \% 16 \mathrm{~S}$ rRNA gene sequence similarity with respect to Rva. nubinhibens ISM $^{\mathrm{T}}$ and $94.9-96.0 \%$ similarity with respect to the type strains of the other Roseovarius species.

The predominant ubiquinone detected in strain SMK- $122^{\mathrm{T}}$ was Q-10 (at a peak area ratio of approximately $97 \%$ ). The cellular fatty acid profile of strain SMK- $122^{\mathrm{T}}$ is shown in Table 2 together with those of Roseovarius species analysed in this study. Strain SMK- $122^{\mathrm{T}}$ contained large amounts of

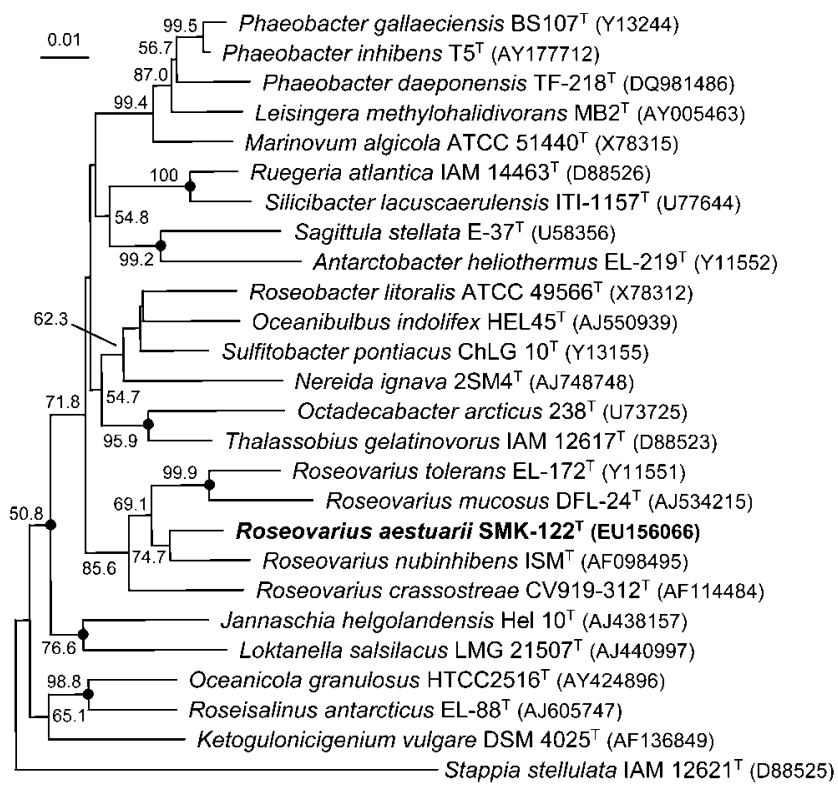

Fig. 1. Neighbour-joining phylogenetic tree, based on $16 \mathrm{~S}$ rRNA gene sequences, showing the positions of strain SMK-122 ${ }^{\top}$, Roseovarius strains and some other related taxa. Bootstrap percentages (based on 1000 replications) $>50 \%$ are shown at branch points. Filled circles indicate that the corresponding nodes were also recovered in the trees generated with the maximumlikelihood and maximum-parsimony algorithms. The sequence of Stappia stellulata IAM $12621^{\top}$ was used as an outgroup. Bar, 0.01 substitutions per nucleotide position.

unsaturated and straight-chain fatty acids, the major components ( $>10 \%$ of total fatty acids) being $\mathrm{C}_{18: 1} \omega 7 \mathrm{c}$ and $\mathrm{C}_{16: 0}$. This fatty acid profile of strain SMK- $122^{\mathrm{T}}$ was similar to those of the type strains of the four recognized Roseovarius species, although there were differences in the proportions of some fatty acids (Table 2 ). The DNA $\mathrm{G}+\mathrm{C}$ content of strain SMK- $122^{\mathrm{T}}$ was $58.6 \mathrm{~mol} \%$. The data obtained from these chemotaxonomic analyses supported the results from the phylogenetic analysis, i.e. that strain SMK- $122^{\mathrm{T}}$ appeared to belong to the genus Roseovarius.

Strain SMK- $122^{\mathrm{T}}$ exhibited a mean DNA-DNA relatedness value of $13 \%$ with respect to Rva. nubinhibens DSM $15170^{\mathrm{T}}$. Strain SMK- $122^{\mathrm{T}}$ is distinguishable from recognized Roseovarius species through differences in several phenotypic characteristics, as listed in Table 1. The phylogenetic and genetic distinctiveness and differential phenotypic properties of strain SMK $-122^{\mathrm{T}}$ are sufficient to categorize it as a member of a novel species of the genus Roseovarius (Wayne et al., 1987; Stackebrandt \& Goebel, 1994). On the basis of the data presented, therefore, strain SMK- $122^{\mathrm{T}}$ represents a novel species of the genus Roseovarius, for which the name Roseovarius aestuarii sp. nov. is proposed. 
Table 2. Cellular fatty acid compositions (\%) of strain SMK $-122^{\top}$ and Roseovarius type strains

Strains: 1 , SMK $-122^{\mathrm{T}}$; 2, Rva. tolerans DSM $11457^{\mathrm{T}}$; 3, Rva. nubinhibens DSM $15170^{\mathrm{T}}$; 4, Rva. crassostreae DSM $16950^{\mathrm{T}}$; 5, Rva. mucosus DSM $17069^{\mathrm{T}}$. Data are from this study. Fatty acids that represented $<0.5 \%$ in all strains were omitted. -, Not detected; ECL, equivalent chain length.

\begin{tabular}{|c|c|c|c|c|c|}
\hline Fatty acid & 1 & 2 & 3 & 4 & 5 \\
\hline \multicolumn{6}{|l|}{ Straight-chain fatty acids } \\
\hline $\mathrm{C}_{12: 0}$ & 5.1 & - & 5.1 & - & 6.6 \\
\hline $\mathrm{C}_{15: 0}$ & 0.2 & 1.9 & 0.6 & - & - \\
\hline $\mathrm{C}_{16: 0}$ & 16.2 & 10.3 & 13.8 & 11.8 & 8.1 \\
\hline $\mathrm{C}_{17: 0}$ & 0.3 & 5.8 & 0.6 & 0.3 & 0.3 \\
\hline $\mathrm{C}_{18: 0}$ & 1.0 & 1.2 & 0.9 & 1.5 & 1.0 \\
\hline \multicolumn{6}{|l|}{ Unsaturated fatty acids } \\
\hline $\mathrm{C}_{17: 1} \omega 8 c$ & 0.2 & 1.0 & - & - & - \\
\hline $\mathrm{C}_{18: 1} \omega 7 c$ & 68.0 & 67.4 & 58.5 & 77.9 & 65.1 \\
\hline \multicolumn{6}{|l|}{ Hydroxy fatty acids } \\
\hline $\mathrm{C}_{10: 0} 3-\mathrm{OH}$ & 0.2 & - & - & 2.0 & 1.0 \\
\hline $\mathrm{C}_{12: 0} 2-\mathrm{OH}$ & - & 0.6 & - & - & 1.5 \\
\hline $\mathrm{C}_{12: 0} 3-\mathrm{OH}$ & 5.3 & - & 2.3 & 0.1 & 0.3 \\
\hline $\mathrm{C}_{12: 1} 3-\mathrm{OH}$ & - & 2.6 & - & - & 2.8 \\
\hline $\mathrm{C}_{16: 0} 2-\mathrm{OH}$ & - & 0.9 & - & - & 4.6 \\
\hline $\mathrm{C}_{16: 0} 3-\mathrm{OH}$ & - & - & - & 0.6 & - \\
\hline $\mathrm{C}_{18: 1} \omega 7 c$ 11-methyl & 0.8 & 6.1 & - & 1.5 & 0.9 \\
\hline $\mathrm{C}_{19: 0} \omega 8 c$ cyclo & 1.5 & 0.2 & 14.2 & - & 4.3 \\
\hline \multicolumn{6}{|l|}{ Summed features ${ }^{*}$} \\
\hline 3 & 0.6 & 0.6 & 1.5 & 2.2 & 1.0 \\
\hline 7 & - & 0.3 & - & - & 1.3 \\
\hline Unknown ECL 11.799 & 0.2 & - & 0.6 & - & 0.9 \\
\hline
\end{tabular}

${ }^{*}$ Summed features represent groups of two or three fatty acids that could not be separated by GLC with the MIDI system. Summed feature 3 contained $\mathrm{C}_{16: 1} \omega 7 c$ and/or iso- $\mathrm{C}_{15: 0}$ 2-OH. Summed feature 7 contained $\mathrm{C}_{19: 1} \omega 6 c, \mathrm{C}_{19: 0} \omega 10 c$ cyclo and/or unknown fatty acid ECL 18.846.

\section{Description of Roseovarius aestuarii sp. nov.}

Roseovarius aestuarii (aes.tu'a.ri.i. L. gen. n. aestuarii of the tidal flat, the place from which the type strain was isolated).

Cells are Gram-negative and ovoid to rod-shaped $(0.3-$ $0.6 \times 0.8-3.5 \mu \mathrm{m})$. Motile by means of single polar flagella. Colonies on MA are circular, raised to slightly convex, glistening, smooth, cream-coloured and $1.0-1.5 \mathrm{~mm}$ in diameter after 7 days incubation at $30{ }^{\circ} \mathrm{C}$. Growth occurs at 10 and $37{ }^{\circ} \mathrm{C}$, but not at 4 or $38{ }^{\circ} \mathrm{C}$. The optimal pH for growth is between 7.0 and 8.0; growth occurs at $\mathrm{pH} 6.0$, but not at $\mathrm{pH} 5.5$. Growth occurs in the presence of $7 \%$ (w/v) $\mathrm{NaCl}$, but not in the absence of $\mathrm{NaCl}$ or in the presence of more than $8 \%(\mathrm{w} / \mathrm{v}) \mathrm{NaCl}$. Anaerobic growth does not occur on MA or on MA supplemented with nitrate. Bacteriochlorophyll $a$ is not produced. $\mathrm{H}_{2} \mathrm{~S}$ is not produced. The predominant ubiquinone is $\mathrm{Q}-10$. The major fatty acids ( $>10 \%$ of total fatty acids) are $\mathrm{C}_{18: 1} \omega 7 c$ and $\mathrm{C}_{16: 0}$. The DNA $\mathrm{G}+\mathrm{C}$ content of the type strain is $58.6 \mathrm{~mol} \%$ (determined by HPLC). Other phenotypic characteristics are given in Table 1.

The type strain, SMK-122 ${ }^{\mathrm{T}}$ (=KCTC $22174^{\mathrm{T}}=\mathrm{CCUG}$ $55325^{\mathrm{T}}$ ), was isolated from a tidal flat sediment of the Yellow Sea at Saemankum, Korea.

\section{Acknowledgements}

This work was supported by the 21C Frontier Program of Microbial Genomics and Applications (grant MG05-0401-2-0) from the Ministry of Science and Technology (MOST) of the Republic of Korea.

\section{References}

Baumann, P. \& Baumann, L. (1981). The marine Gram-negative eubacteria: genera Photobacterium, Beneckea, Alteromonas, Pseudomonas, and Alcaligenes. In The Prokaryotes, pp. 1302-1331. Edited by M. P. Starr, H. Stolp, H. G. Trüper, A. Balows \& H. G. Schlegel. Berlin: Springer.

Biebl, H., Allgaier, M., Lünsdorf, H., Pukall, R., Tindall, B. J. \& Wagner-Döbler, I. (2005). Roseovarius mucosus sp. nov., a member of the Roseobacter clade with trace amounts of bacteriochlorophyll $a$. Int J Syst Evol Microbiol 55, 2377-2383.

Boettcher, K. J., Geaghan, K. K., Maloy, A. P. \& Barber, B. J. (2005). Roseovarius crassostreae sp. nov., a member of the Roseobacter clade and the apparent cause of juvenile oyster disease (JOD) in cultured Eastern oysters. Int J Syst Evol Microbiol 55, 1531-1537.

Bruns, A., Rohde, M. \& Berthe-Corti, L. (2001). Muricauda ruestringensis gen. nov., sp. nov., a facultatively anaerobic, appendaged bacterium from German North Sea intertidal sediment. Int $J$ Syst Evol Microbiol 51, 1997-2006. 
Cohen-Bazire, G., Sistrom, W. R. \& Stanier, R. Y. (1957). Kinetic studies of pigment synthesis by nonsulfur purple bacteria. J Cell Comp Physiol 49, 25-68.

Cowan, S. T. \& Steel, K. J. (1965). Manual for the Identification of Medical Bacteria. London: Cambridge University Press.

Ezaki, T., Hashimoto, Y. \& Yabuuchi, E. (1989). Fluorometric deoxyribonucleic acid-deoxyribonucleic acid hybridization in microdilution wells as an alternative to membrane filter hybridization in which radioisotopes are used to determine genetic relatedness among bacterial strains. Int J Syst Bacteriol 39, 224-229.

González, J. M., Covert, J. S., Whitman, W. B., Henriksen, J. R., Mayer, F., Scharf, B., Schmitt, R., Buchan, A., Fuhrman, J. A. \& other authors (2003). Silicibacter pomeroyi sp. nov. and Roseovarius nubinhibens sp. nov., dimethylsulfoniopropionate-demethylating bacteria from marine environments. Int J Syst Evol Microbiol 53, 1261-1269.

Komagata, K. \& Suzuki, K. (1987). Lipid and cell-wall analysis in bacterial systematics. Methods Microbiol 19, 161-207.

Labrenz, M., Collins, M. D., Lawson, P. A., Tindall, B. J., Schumann, P. \& Hirsch, P. (1999). Roseovarius tolerans gen. nov., sp. nov., a budding bacterium with variable bacteriochlorophyll a production from hypersaline Ekho Lake. Int J Syst Bacteriol 49, 137-147.

Lányí, B. (1987). Classical and rapid identification methods for medically important bacteria. Methods Microbiol 19, 1-67.

Leifson, E. (1963). Determination of carbohydrate metabolism of marine bacteria. J Bacteriol 85, 1183-1184.
Sasser, M. (1990). Identification of bacteria by gas chromatography of cellular fatty acids, MIDI Technical Note 101. Newark, DE: MIDI Inc.

Stackebrandt, E. \& Goebel, B. M. (1994). Taxonomic note: a place for DNA-DNA reassociation and $16 \mathrm{~S}$ rRNA sequence analysis in the present species definition in bacteriology. Int J Syst Bacteriol 44, 846-849.

Staley, J. T. (1968). Prosthecomicrobium and Ancalomicrobium: new prosthecate freshwater bacteria. J Bacteriol 95, 1921-1942.

Tamaoka, J. \& Komagata, K. (1984). Determination of DNA base composition by reversed-phase high-performance liquid chromatography. FEMS Microbiol Lett 25, 125-128.

Wayne, L. G., Brenner, D. J., Colwell, R. R., Grimont, P. A. D., Kandler, O., Krichevsky, M. I., Moore, L. H., Moore, W. E. C., Murray, R. G. E. \& other authors (1987). International Committee on Systematic Bacteriology. Report of the ad hoc committee on reconciliation of approaches to bacterial systematics. Int J Syst Bacteriol 37, 463-464.

Yoon, J.-H., Kim, H., Kim, S.-B., Kim, H.-J., Kim, W. Y., Lee, S. T., Goodfellow, M. \& Park, Y.-H. (1996). Identification of Saccharomonospora strains by the use of genomic DNA fragments and rRNA gene probes. Int J Syst Bacteriol 46, 502-505.

Yoon, J.-H., Lee, S. T. \& Park, Y.-H. (1998). Inter- and intraspecific phylogenetic analysis of the genus Nocardioides and related taxa based on $16 \mathrm{~S}$ rRNA gene sequences. Int J Syst Bacteriol 48, 187-194.

Yoon, J.-H., Kang, K. H. \& Park, Y.-H. (2003). Psychrobacter jeotgali sp. nov., isolated from jeotgal, a traditional Korean fermented seafood. Int J Syst Evol Microbiol 53, 449-454. 